\title{
PERILAKU PENCARIAN INFORMASI PARIWISATA PARA WISATAWAN DOMESTIK DI RUMAH MODE
}

\author{
Ghanis Haryendra Damara ${ }^{1}$, Pawit M.Yusup ${ }^{2}$, Rully Khaerul A. ${ }^{3}$ \\ ${ }^{1,2,3}$ Program Studi Ilmu Perpustakaan Universitas Padjadjaran \\ 1.ghanisharyendra@yahoo.com, 2pawit.m.yusup@unpad.ac.id, \\ 3rully.khairul@unpad.ac.id
}

\begin{abstract}
This thesis is titled "Tourism Information Searching Behaviours of Domestic Tourist In The City Of Bandung Rumah Mode". The method used in this thesis is a qualititative method. Study of theory used in this study is Information Seeking Behavior Theory (Wilson). Data collection techniques used are observation, interview and documentation study. From the observation of researchers by going directly to the Rumah Mode, tourist arrivals generally have an incentive and motivation that is fulfill the shopping needs with a variety of branded clothing and underwear from young to old. Knowledge about the safety of domestic tourist on Rumah Mode actually varied according to what they are looking. So far the treatment of domestic tourist to the information that was obtained was made of feed back to the Rumah Mode. The general interest of domestic tourist to come to Rumah Mode is almost the same, because tourist can see bt itself on the facilities provided for the convenience of Rumah Mode tourist. Satisfaction at Rumah Mode is calssified into three aspects of satisfaction. Namely, satisfaction with the quality of goods, price and service the Rumah Mode. So far, the tourist were satisfied with what already exist in the Rumah Mode, but there are also tourists who are not satisfied because there is little interference due to renovation of the parking lot.
\end{abstract}

Keywords: Information Seeking Behavior, Tourism, Rumah Mode

ABSTRAK - Skripsi ini berjudul "Perilaku Pencarian Informasi Pariwisata Para Wisatawan Domestik Kota Bandung di Rumah Mode". Metode yang digunakan dalam skripsi ini adalah metode kualitatif. Kajian teori yang digunakan dalam penelitian ini adalah Teori Information Seeking Behavior (Wilson). Teknik pengumpulan data yang digunakan yaitu observasi, wawancara, dan studi dokumentasi. Dari hasil observasi peneliti dengan terjun langsung ke Rumah Mode ini, umumnya wisatawan yang datang mempunyai tujuan dan motivasi yaitu memenuhi kebutuhan hidupnya dengan berbelanja aneka pakaian dan celana yang bermerk dari kalangan muda sampai kalangan tua. Pengetahuan wisatawan domestik tentang keamanan Rumah Modesejauh ini umumnya merasa nyaman. Dilihat dari segi aspek parkir, keamanan dan pelayanannya Rumah Mode sudah memberikan yang terbaik. Pengalaman wisatawan domestik tentang Rumah Mode ini sebenarnya beraneka ragam sesuai dengan kebutuhan yang mereka cari. Sejauh ini perlakuan wisatawan domestik terhadap informasi yang sudah di dapat memang membuat adanya feed back kepada Rumah Mode. Pada umumnya ketertarikan wisatawan domestik untuk datang ke Rumah Mode ini hampir sama, karena wisatawan dapat melihat dengan sendirinya tentang apa saja fasilitas yang disediakan dari Rumah Mode untuk kenyamanan wisatawannya. Kepuasan berada di Rumah Mode ini tergolong terjadi tiga aspek kepuasan. Yaitu, kepuasan terhadap kualitas barang, kepuasan terhadap kualitas harga, dan yang terakhir kualitas terhadap aspek pelayanan Rumah Mode tersebut. Sejauh ini, wisatawan merasa puas dengan apa yang sudah ada di Rumah Mode ini, namun ada juga wisatawan yang merasa tidak puas karena adanya sedikit gangguan akibat renovasi lapangan parkir di dalam Rumah Mode ini.

Kata Kunci: Perilaku Pencarian Informasi, Pariwisata, Rumah Mode

\section{PENDAHULUAN}

Perilaku adalah respon individu terhadap suatu stimulus atau suatu tindakan yang dapat diamati dan mempunyai frekuensi spesifik, durasi dan tujuan baik disadari maupun tidak. Perilaku juga merupakan kumpulan berbagai faktor yang saling berinteraksi. Sering tidak disadari bahwa interaksi tersebut amat kompleks sehingga 
kadang-kadang kita tidak sempat memikirkan penyebab seseorang menerapkan perilaku tertentu. Karena itu amat penting untuk dapat menelaah alasan dibalik perilaku individu tersebut.

Pariwisata merupakan salah satu potensi sumber daya yang dapat dikembangkan oleh setiap daerah, sebagai salah satu sumber daya yang menghasilkan devisa bagi negara.pengoptimalan potensi kawasan wisata didasari bahwa pariwisata merupakan sektor yang lebih menekankan pada suatu penyediaan jasa dengan mengoptimalkan potensi tersebut. Dan salah satu kota di Indonesia yang berpotensi sebagai tempat wisata dan memiliki keunikan dalam menarik para wisatawan adalah Bandung yang dapat menyuguhkan berbagai tempat wisata mulai dari wisata alam, wisata kuliner, wisata belanja dan wisata sejarah.

Factory Outlet adalah salah satu pusat wisata belanja yan paling menonjol di Bandung. Saat ini factory outlet yang tersebar di seluruh kota Bandung (selain pusat jeans Cihampelas dan Tamim) ada sekita 200 counter (Asosiasi Wisata Bandung, 2007), kendati yang memenuhi syarat untuk bisa disebut factory outlet hanya ada sekitar 90 counter.

Banyaknya factory outlet di wilayah Jawa Barat (khususnya kota Bandung) diimbangi dengan banyaknya wisatawan baik mancanegara maupun domestik untuk berkunjung ke Bandung. Hal ini dapat dilihat dari meningkatnya jumlah penjualan barang di factory outlet (Asosiasi Wisata Bandung, 2007).

Factory Outlet berangkat dari pakaian sisa export. Seperti diketahui bahwa Indonesia memproduksi pakaian-pakaian untuk di export ke luar negeri seperti Singapore, Korea Selatan, dll. Di negara tersebut, pakaian dari Indonesia kemudian di beli label baru / re-label untuk kemudian di export kembali ke pasar Eropa atau Amerika. Hal ini dilakukan karena biaya produksi di Indonesia relativ elebih murah. Sebagai contoh, perusahaan pakaian merk terkenal DAP memproduksi pakaian di Indonesia. Ini dapat menjelaskan bahwa kualitas bahan dari pakaian yang dijual di FO tidak perlu diragukan lagi.

Salah satu kebutuhan mendasar baik individu maupun masyarakat adalah kebutuhan informasi. Informasi memang sudah menjadi kebutuhan manusia yang essensial untuk berbagai tujuan (Rachmadi, 1990:22). Oleh karena itu, peneliti tertarik untuk mengadakan penelitian ini karena Bandung merupakan salah satu dar sekian banyak kota yang dipilih oleh wisatawan, baik wisatawan dalam maupun luar.

\section{TINJAUAN PUSTAKA}

Perilaku (behaviour) dapat diartikan sebagai (a) tingkah laku yang ditimbulkan dari diri seseorang (b) segala sesuatu yang dilakukan oleh benda hidup yang meliputi tindakan dan respon terhadap rangsangan serta (c) respon seseorang, sekelompok orang atau spesies terhadap lingkungan (Salim, 1996). Perilaku pencarian informasi dalam pembahasan psikologi merupakan suatu proses kognitif dalam bentuk keterampilan yang sangat berkaitan dengan sikap, pandangan, dan penilaian seseorang terhadap objek tertentu, perilaku tersebut ada yang nampak 
(over behaviour) dan ada yang tidak nampak atau tersembunyi (covert behaviour).

Dalam hal perilaku pencarian guna menentukan informasi yang diinginkan, teori kognitif yang mendekati atau dianggap tepat adalah yang diungkapkan oleh F. Heider, seperti yang dikutip oleh Sarlito Wirawan (Sarwono, 2002: 159) bahwa dorongan manusia untuk mencari atribusi dari suatu gejala atau perilaku orang lain disebabkan karena dua motif yang sangat kuat pada manusia, yaitu (1) kebutuhan untuk mengerti keadaan lingkungan sekelilingnya dan (2) kebutuhan untuk sampai batas tertentu dapat mengendalikan lingkungannya. Oleh karena itu, setiap perilaku akan diberi dari salah satu dari dua kemungkinan atribusi, yaitu (1) internal dan (2) eksternal.

Pendapat yang lebih rinci dikemukakan oleh Diao yang dikutip oleh Luki Wijayanti (Wijayanti, 2004) mengatakan bahwa perilaku pencarian informasi merupakan aktifitas pemakai untuk mencari, mengumpulkan dan memakai informasi yang mereka butuhkan. Sedangka Auster (Auster, 1982: 178) mendefinisikan perilaku-perilaku informasi sebagai kaitan antara siapa, membutuhkan informasi macam apa dan untuk alasan apa; bagaimana informasi dapat ditemukan; dievaluasi dan digunakan; dan bagaimana kebutuhan-kebutuhan ini dapat diidentifikasi dan dipenuhi.

Darvin dan Milan yang dikutip Panen (1990; 29-30) mengatakan informasi ialah sebagai berita, segala dokumen, segala data atau segala bahan yang diterbitkan. Hal tersebut berarti informasi dapat menjadi media komunikasi.
Sebaliknya, data adalah informasi yang belum pernah diolah, belum berkelompok dan seringkali tidak terkait satu sama lain (Campbell,1997). Untuk melihat perbedaan antara informasi dan data, serta pengetahuan Teskey (dalam Pendit, 1992;80-81) membedakan ketiga kata sebagai berikut:

1. Data adalah hasil observasi langsung terhadap suatu kejadian atau keadaan, data merupakan entitas yang dilengkapi dengan nilai tertentu. Entitas ini merupakan perlambangan yang mewakili objek atau konsep dalam dunia nyata.

2. Informasi adalah kumpulan data yang terstruktur untuk memperlihatkan adanya hubungan entitas tersebut.

3. Pengetahuan adalah model yang digunakan manusia untuk memahami dunia, dan dapat diubah-ubah oleh informasi yang diterima pikiran manusia.

Pariwisata menurut Lundberg (1997) adalah konsep umum yang sejarahnya kembali ke masa yang lampau, dan definisi selalu berubah. Istilah touris atau kepariwisataan mencakup orang-orang yang melakukan perjalanan pergi dari rumahnya, dan perusahaan-perusahaan yang memperlancar atau mempermudah perjalanan mereka atau membuat lebih menyenangkan.

Pariwisata merupakan gabungan antara kegiatan jasa atau industri penyedia pelayanan kepada wisatawan yang dapat memberi suatu pengalaman kepada wisatawan yaitu transportasi, akomodasi, jasa boga, pusat perbelanjaan, hiburan, fasilitas dan jasa lainnya. Yang disediakan bagi mereka yang berpergian jauh dari rumah. 
Secara jelas dapat dilihat bahwa pariwisata bukanlah merupakan suatu industri seperti sama halnya dengan industri barang jadi seperti mesin, perabot dan barang jadi lainnya yang mempunyai pabrik pembuatan dan yang mengahsilkan barang-barang yang secara langsung dapat dikonsumsi oleh masyarakat seabgai hasil produksinya.

Sebenarnya pariwisata lebih tepat disebut sebagai suatu kegiatan, tetapi jika dilihat dari sudut ekonomi aktivitas tersebut menciptakan permintaan yang memerlukan pemasaran dari produk aktivitasnya.

Bentuk pariwisata menurut Pendit (Ilmu pariwisata, sebuah pengantar perdana, 1990) dapat dibagi menurut kategori antara lain; menurut asal wisatawan, menurut akibatnya terhadap neraca pembayaran, menurut jangka waktu, menurut jumlah wisatawan dan menurut alat angkut yang dipergunakan (Karyono, 1997:16).

Definisi jenis-jenis pariwisata menurut Valene L. Smith (1991) yang terdapat dalam kosa kata kepariwisatawan antara lain:

1. Pariwisata Pantai (Marine Tourism) adalah kegiatan pariwisata yang ditunjang oleh sarana dan prasarana untuk berenang, memancing, menyelam dan olah raga air lain termasuk sarana prasarana akomodasi, makan dan minum.

2. Pariwisata Etnik (Ethnic Tourism) adalah kegiatan pariwisata yang mengamati perwujudan kebudayaan dan gaya hidup masyarakat yang dianggap menarik.

3. Pariwisata Budaya (Culture Tourism) adalah perjalanan untuk meresapi suatu gaya hidup yang hilang dari ingatan manusia.

4. Pariwisata Rekreasi (Recreational Tourism) adalah kegiatan wisata yang berkisar pada olah raga, menghilangkan ketegangan dan melakukan kontak sosial dalam suasana santai.

5. Pariwisata Kota (City Tourism) adalah perjalanan dalam satu kota untuk melihat, mempelajari, mengalami objek, sejarah dan daya tarik yang terdapat di kota tersebut.

6. Pariwisata Alam (Ecotourism) adalah perjalanan ke suatu tempat yang relatif masih alami dengan tujuan untuk mempelajari, mengagumi, menikmati pemandangan, tumbuhan dan binatang liar, serta perwujudan budaya yang ada atau penah ada pada suatu tempat.

7. Resort City adalah suatu kota yang memiliki tumpuan kehidupan pada penyediaan sarana dan prasarana wisata, yaitu penginapan, restoran, olahraga, hiburan dan penyedia jasa wisata lainnya.

8. Pariwisata Agro (Agro Tourism) adalah kegiatan perjalanan untuk menikmati kegiatan pertanian, perkebunan, peternakan dan kehutanan. Jenis wisata ini bertujuan untuk mengajak wisatawan untuk lebih memperhatikan sumber daya alam dan kelestariannya.

9. Pariwisata Sosial (Social Tourism) adalah sautu pendekatan untuk menyelenggarakan liburan bagi kelompok masyarakat berpenghasilan rendah serta orang-orang 
yang tidak memiliki inisiatif untuk melakukan perjalanan.

10. Pariwisata Alternatif (Alternatif Tourism) adalah suatu bentuk pariwisata yang sengaja disusun dalam skala kecil, memperhatikan kelestarian lingkungan dan segi-segi sosial.

Pengertian wisatawan yang digunakan oleh Sukadijo (1996:13) bahwa wisatawan adalah orang yang selama 24 jam atau lebih mengadakan perjalanan di negara yang bukan tempat tinggalnya yang biasa. Menurut pengertian tersebut, semua orang yang melakukan kegiatan perjalan wisata dinamakan wisatawan apapun tujuannya yang penting perjalanan itu bukan untuk menetap dan untuk mencari nafkah ditempat yang dikunjungi.

Ciri-ciri wisatawan adalah melakukan suatu perjalanan diluar tempat tinggal, sehubungan dengan berbagai keperluan seperti rekreasi, liburan, kesehatan, pendidikan, tugas-tugas, pekerjaan, usaha bisnis, kesenian, ilmu pengetahuan, ibadah, olahraga, pameran. dan melakukan perjalanan dan persinggahan di tempat lain untuk sementara waktu tanpa bermaksud untuk memperoleh penghasilan tetap di tempat yang dikunjungi.

Definisi berbeda dikemukakan oleh Pendit bahwa wisatawan yaitu:

1. Orang-orang yang sedang mengadakan perjalanan untuk bersenang-senang, untuk keperluan pribadi, untuk keperluan kesehatan dan sebagainya.

2. Orang-orang yang sedang mengadakan perjalanan untuk bermaksud mengahadiri pertemuan, konferensi, musyawarah, atau di dalam hubungan sebagai utusan berbagai badan/organisasi (ilmu pengetahuan, administrasi, diplomatik, olahraga, keagamaan, dan seabagainya).

3. Orang-orang yang sedang mengadakan perjalanan dengan maksud bisnis.

4. Pejabat pemerintah dan orang-orang militer beserta keluarganya yang mengadakan perjalanan ke negara lain. (Pendit, 2002:36).

Jenis wisatawan dapat dibedakan menjadi dua macam (Musanef, 1995:14), yaitu wisatawan mancanegara yang merupakan seorang yang mengadakan perjalanan untuk melihat sesuatu yang lain dan kemudian mengetahui bila ia membayar sesuatu yang telah sesuai. Jelasnya, wisatawan mancanegara adalah setiap orang yang bukan penduduk Indonesia yang melakukan perjalanan atau persinggahan sementara ke wilayah geografis Indonesia untuk keperluan apapun kecuali mencari penghasilan atau nafkah. Lalu wisatawan nusantara adalah seorang penduduk yang melakukan perjalanan ke tempat selain dimana ia tinggal menetap (Musanef, 1995:14).

Wisatawan domestik yang berkunjung ke Bandung tentunya memiliki tujuan tertentu untuk datang ke kota wisata ini, seperti untuk liburan, keperluan keluarga keperluan kesehatan, keperluan bisnis, tugas kantor dan kerabat dekat.

Motivasi merupakan hal yang sangat mendasar dalam mempelajari mengenai wisatawan dan pariwisata, karena motivasi merupakan dorongan dari proses perjalan wisata. 
Motivasi dapt diklasifikasikan menjadi empat, yaitu:

1. Physical motivation yaitu motivasi yang bersifat fisik, antara lain untuk relaksasi, kesehatan, kenyamanan, berpartisipasi alam kegiatan olahraga, bersantai dan sebagainya.

2. Cultural motivation yaitu keinginan untuk mengetahui budaya, adat, tradisi, dan kesenian daerah lain. Termasuk juga ketertarikan akan berbagai objek peninggalan budaya.

3. Fantasy motivation yaitu motivasi yang bersifat sosial, seperti mengunjungi teman dan keluarga, menemui mitra kerja, melakukan hal-hal yang dianggap mendatangkan gengsi (prestise), melakukan ziarah, pelarian dari situasi yang membosankan. Atau dapat juga motivasi bahwa di daeah lain seseorang akan bisa lepas dari rutinitas keseharian yang menjemukan dan memberikan kepuasan psikologi.

Dipilihnya Kota Bandung untuk menjaring wisatawan domestik maupun mancanegara dengan petimbangan Kota Bandung merupakan objek wisata instan. Selain menawarkan berbagai objek wisata, akomodasi yang semakin lengkap menjadikan Kota Bandung sebagai salah satu kota tujuan utama wisatawan mancanegara asal Singapura dan Malaysia serta negara Eropa Barat.

Pengaruh keamanan terhadap pariwisata sebetulnya sangat jelas, tetapi banyak tempat wisata yang berkembang tidak memasukkannya dalam perencanaan pengembangan pariwisata mereka sebelum masalah-masalah yang ditimbulkan oleh faktor ketidakamanan terjadi.

Pariwisata merupakan gejala dari pergerakan manusia secara temporer dan spontan di dalam rangka memenuhi kebutuhan dan keinginan tertentu. Gejala-gejala tersebut mendorong dan menumbuhkan kegiatan- kegiatan dalam bidang konsumsi dan produksi barang dan jasa-jasa yang diperlukan oleh wisatawan.

Timbulnya keinginan wisatawan tersebut, biasanya timbul karena pengaruh kondisi dan sifat-sifat lingkungan dimana wisatawan tersebut berada. Kebutuhan dan keinginan ini kadang-kadang sangat mendalam. Misalnya, keinginan untuk mendapatkan pengalam baru, keinginan untuk melepaskan diri dari kekangan-kekangan dan lain-lain.

Selama ini wisatawan mencari informasi melalui informan-informan yang tersedia, misalnya melalui internet, jejaring sosial, koran, majalah, teman atau kerabat dekat dan lain sebagainya. Informasi bisa di dapat dimanapun sesuai dengan kebutuhannya. Wisatawan yang mencari informasi seputar kota wisata yang akan mereka kunjungi tentu akan semakin memudahkan wisatawan menikmati nikmatnya berwisata belanja di Rumah Mode.

Ketertarikan wisatawan untuk datang ke Kota Bandung, mengingat Bandung dikenal diluaran sana sebagai Paris Van Java yang mempunyai keanekaragaman jenis wisata yang mampu menarik wisatawan untuk datang dan kembali lagi ke Kota Bandung.

Kepuasan konsumen (wisatawan) telah menjadi konsep sentral dalam teori dan aplikasi 
pemasaran, serta merupakan salah satu tujuan esensial bagi aktifitas bisnis. Kepuasan konsumen juga dipandang sebagai salah satu indikator terbaik untuk meraih laba di masa yang akan datang (Fornell, 1992; Kotler, 2000). Fakta yang menunjukkan bahwa menarik konsumen baru lebih mahal daripada mempertahankan konsumen yang ada, juga menjadi pemicu meningkatnya upaya untuk menjaga kepuasan.

Kata kepuasan atau satisfaction berasal dari bahasa latin "satis" yang berarti cukup baik atau memadai dan "facio" yang berarti melakukan atau membuat. Kepuasan merupakan salah satu indikator yang mempengaruhi loyalitas. Semakin tinggi tingkat kepuasan, maka loyalitas akan semakin tinggi. Sehubungan dengan hal tersebut, Zeithmal dan Britner (2003) menyatakan bahwa satisfaction merupakan pemenuhan respon konsumen. Pendapat tersebut ditegaskan oleh Kotler (2006) yang mendefinisikan kepuasan pelanggan sebagai perasaan senang atau kecewa seseorang yang berasal dari pembandingan kinerja suatu produk dan jasa dengan harapan.

\section{METODE PENELITIAN}

Penelitian ini menggunakan penelitian kualitatif, melalui penelitian kualitatif ini mengandung suatu penggambaran atas data dengan menggunakan kata dan baris kalimat. Penelitian kulaitatif menggunakan metode kualitatif yaitu pengamatan, wawancara, atau penelaah dokumen.

\section{HASIL DAN PEMBAHASAN}

Wisatawan domestik yang berkunjung ke Bandung tentunya memiliki tujuan tertentu untuk datang ke kota wisata ini, seperti untuk liburan, keperluan keluarga, keperluan kesehatan, keperluan bisnis, tugas kantor dan mengunjungi teman dan kerabat dekat.

Motivasi merupakan hal yang sangat mendasar dalam mempelajari mengenai wisatawan dan pariwisata, karena motivasi merupakan dorongan dari proses perjalanan wisata.

Pada hakekatnya tujuan dan motivasi seorang wisatwan domestik itu bergantung pada kebutuhan yang mereka inginkan. Menurut peneliti, tidak menutup kemungkinan juga wisatawan yang datang tidak hanya sekedar mencari apa kebutuhan apa yang mereka inginkan, wisatawan yang datang juga bisa berwisata dengan cara yang tidak seangaja. Misalnya, seseorang yang menjadi pramuwisata (guide) secara tidak langsung juga dapat melakukan wisata belanja dengan membeli sebuah barang yang menurutnya itu unik. Selain menjadi pramuwisata juga bisa menjadi wisatawan.

Faktor keamanan pun harus jelas di bidang pariwisata. Pihak pariwisata harus peka terhadap keadaan sosial-budaya dan sosial-ekonomi masyarakat sekitar kawasan wisata, agar konflik antar masyarakat dengan pihak pengusaha pariwisata dan wisatawan dapat dihindarkan.

Pengetahuan wisatawan domestik tentang keamanan Rumah Mode sejauh ini umumnya merasa nyaman. Dilihat dari segi aspek parkir, keamanan dan pelayanannya Rumah Mode sudah memberikan yang terbaik walaupun menurut 
Bapak Sam selaku PR \& Production pada waktu itu kenyamanan wisatawan agak terganggu karena ada wisatawan yang kehilangan barang-barang mereka. Namun kendala ini dapat diatasi oleh pihak Rumah Mode dengan cara lebih meningkatkan kualitas keamanan dengan menambahkan lagi petugas-petugas keamanan demi terciptanya suasana yang nyaman berada di Rumah Mode ini.

Dari hasil observasi peneliti dengan terjun langsung ke Rumah Mode ini, umumnya wisatawan yang datang mempunyai tujuan dan motivasi yaitu memenuhi kebutuhan hidupnya dengan berbelanja aneka pakaian dan celana yang bermerk dari kalangan muda sampai kalangan tua. Selain berbelanja pengunjung yang datang juga bisa berbelanja sambil menikmati beraneka ragam makanan dan minuman yang tersedia di food court Rumah Mode ini.

Semula Rumah Mode berbentuk garmen kecil yang menjual barang-barang sisa ekspor dan seiring berjalannya pada tahun 1999 garmen ini mulia berkembang sehingga menjadi Factory Outlet.

Factory Outlet sebenarnya adalah mereka yang mempunyai pabrik sendiri. Di Bandung ada lima yang memiliki pabrik sendiri yaitu Rumah Mode, Rumah Anak yang berada di Jl. Soekarno Hatta kemudian ada beberapa pabrik lainnya.

Dan untuk Rumah Mode terletak di Jl. Setiabudhi No.41. Saat ini Rumah Mode menjadi icon Kota Bandung apalagi saat weekend datang banyak sekali orang yang berkunjung untuk belanja di Rumah Mode ini.

\section{SIMPULAN}

1. Dari hasil penelitian penulis yang berjudul Perilaku Pencarian Informasi Pariwisata Para Wisatawan Domestik Kota Bandung di Rumah Mode Jln. Setiabudhi No. 41 Bandung adalah wisatawan yang datang mempunyai tujuan dan motivasi untuk memenuhi kebutuhan hidupnya dengan berbelanja aneka pakaian dan celana yang bermerk dari kalangan muda sampai kalangan tua. Lalu pengalaman wisatawan pun beraneka ragam sesuai dengan kebutuhan yang mereka cari. Rumah Mode tidak hanya menyediakan wisata belanjanya saja, mereka juga memanjakan wisatawan dengan menyediakan kuliner yang beraneka ragam.

2. Lalu perlakuan wisatawan terhadap informasi yang sudah didapatkan memberi feedback kepada Rumah Mode. Feed back yang terjadi memang sangat menguntungkan bagi rumah mode, untuk itu perlu sekali adanya penyebaran informasi di berbagai media yang diinginkan oleh pariwisata tersebut.

3. Ketertarikan wisatawan domestik untuk datang ke Rumah Mode ini hampir sama, karena wisatawan dapat melihat dengan sendirinya tentang apa saja fasilitas yang disediakan dari Rumah Mode untuk kenyamanan wisatawannya. Kemudian kepuasan terhadap kuliatas barang, kepuasan terhadap kualitas harga, dan yang terakhir kuliatas terhadap aspek pelayanan Rumah Mode tersebut. 


\section{DAFTAR PUSTAKA}

Amirin, tatang M. (1993). Menyusun Rencana Penelitian. Jakarta: SIC.

Asosiasi Wisata Bandung. (2007).

Auster, Ethel. (1982). Organizational Behaviour and Information Seeking;Lessons For Librarians. Special Library Association. Budiyanto, M. (2000). Kebutuhan Informasi dan Perilaku Pencarian Informasi Peneliti Bidang Ilmu Pengetahuan Sosial dan Kemanusiaan Di Lembaga Ilmu Pengetahuan Indonesia. Depok. (Tidak Diterbitkan).

Campbell, Vincent., et al. (1997). Decisions Based on Science. Arlington VA: National Science Teachers Association.

F. Rachmadi. (1990). Perbandingan Sistem Pers. Jakarta: Gramedia.

Lundberg, Donald E. (1997). EkonomiPariwisata. Jakarta :Gramedia Pustaka Utama.

Moleong, Lexy J. (2000). Metodologi Penelitian Kualitatif. Bandung: Remaja Rosdakarya.

Mulyana, Deddy. (2001). Metodologi Penelitian Kualitatif: Paradigma baru Ilmu Komunikasi dan Ilmu Sosial Lainnya. Bandung: PT Remaja Rosdakarya.

Musanef. (1995). Manajemen Usaha Pariwisata di Indonesia. Jakarta : PT Toko Gunung Agung

Pendit, Putu Laxman. (1992). Makna Informasi: lanjutan dari sebuah perdebatan. Dalam Kepustakawanan Indonesia: potensi dan tantangan. Jakarta: Kesainc Blanc. Hlm.

R. G Soekadijo. (1996). Anatomi Pariwisata. Jakarta: PT Gramedia Pustaka Utama.
Rachmat, Jalaludin. (2002). Psikologi Komunikasi. Bandung: PT Remaja Rosdakarya.

Sarwono, Sarlito Wirawan. (2002). Psikologi Sosial; Indovodu dan Teori-teori Psikologi Sosial. Jakarta: Balai Pustaka.

Wijayanti, Luki et al. (Ed). (2004). Perpustakaan Perguruan Tinggi. Buku Pedoman. Jakarta : Direktorat Jendral Pendidikan Tinggi Depdiknas

Wilsons, T.D. (March 1981). On User Studies and Information Needs. Journal of Documentation. 
